\title{
Peningkatan Kemampuan Evaluasi Guru Melalui Supervisi Klinis di SDN 156/X Tanjung Solok Tahun Ajaran 2021/2022
}

\author{
Asniwati \\ SDN 156/X Tanjung Solok \\ Jl. Parit, Tanjung Solok, Jambi Indonesia \\ asniwati@gmail.com
}

\begin{abstract}
This study aims to obtain data/information and discuss the improvement of teacher evaluation skills through clinical supervision of supervisors at SDN 156/X Tanjung Solok. This research is school action research (PTS) which consists of two cycles by following four stages of planning, implementation, observation, and reflection. This research was conducted at SDN 156/X Tanjung Solok in the odd semester of the 2021/2022 academic year with 6 teachers as the subject. Data were collected through observation sheets and documentation and analyzed using percentages and data reduction. The results of the study show that clinical supervision can improve teacher evaluation abilities.
\end{abstract}

Keywords: Evaluation Ability, Clinical Supervision

\begin{abstract}
Abstrak
Penelitian ini bertujuan untuk mendapatkan data/informasi dan membahas tentang peningkatan kemampuan evaluasi guru melalui supervisi klinis pengawas di SDN 156/X Tanjung Solok. Penelitian ini adalah penelitian tindakan sekolah (PTS) yang terdiri dari dua siklus dengan mengikuti empat tahapan perencanaan, pelaksanaan, observasi dan refleksi. Penelitian ini dilaksanakan di SDN 156/X Tanjung Solok pada semester ganjil tahun ajaran 2021/2022 dengan subjek guru yang berjumlah 6 orang. Data dikumpulkan melalui lembar observasi dan dokumentasi serta dianalisis menggunakan persentase dan reduksi data. Hasil penelitian menujukkan bahwa supervisi klinis dapat meningkatkan kemampuan evaluasi guru.
\end{abstract}

Kata kunci: Kemampuan Evaluasi, Supervisi Klinis.

Copyright (c) 2022 Asniwati

Corresponding author: Asniwati

Email Address: asniwati@gmail.com (Jl. K.H. Muhtar, Tanjung Jabung Timur, Jambi)

Received 10 January 2022, Accepted 20 January 2022, Published 28 January 2022

\section{PENDAHULUAN}

Profesionalitas guru sering dikaitkan dengan tiga faktor yang cukup penting, yaitu kompetensi guru, sertifikasi guru, dan tunjangan profesi guru. Ketiga faktor tersebut merupakan latar yang disinyalir berkaitan erat dengan kualitas pendidikan. Guru profesional yang dibuktikan dengan kompetensi yang dimilikinya akan mendorong terwujudnya proses dan produk kinerja yang dapat menunjang peningkatan kualitas pendidikan. memiliki kompetensi.

Salah satu bentuk aktualisasi tugas guru sebagai tenaga profesional adalah diterbitkannya Undang-Undang Nomor 20 Tahun 2003 tentang Sistem Pendidikan Nasional, Undang Undang No 14 Tahun 2005 tentang Guru dan Dosen dan Peraturan Pemerintah Nomor 19 Tahun 2005 tentang Standar Nasional Pendidikan. Undang-undang dan peraturan pemerintah ini diharapkan dapat memfasilitasi guru untuk selalu mengembangkan keprofesiannya secara berkelanjutan. Dalam kegiatan pembelajaran, seorang guru sudah pasti akan berhadapan dengan berbagai persoalan baik menyangkut peserta didik, sarana prasarana sekolah, maupun metode pembelajaran. Pengembangan sekolah pada dasarnya adalah pengembangan kualitas para gurunya. Salah satu upaya untuk 
mengembangkan kualitas guru adalah meningkatkan kemampuan serta kinerja guru dalam melaksanakan sistem penilaian dan evaluasi. Adanya beberapa indikator penting bagi pengembangan suatu sekolah adalah dengan meningkatkan guru yang mempunyai kemampuan praktis. Salah satu kemampuan praktis yang dimaksud adalah kinerja guru dalam membuat soal.

Kinerja guru dalam mengevaluasi hasil belajar dimulai dari merencanakan materi pembelajaran, membuat Tujuan Pembelajaran Khusus (TPK), membuat kisi-kisi soal, membuat soal itu sendiri, menganalisis butir soal, melaksanakan tes, mengukur, memberi nilai, sampai memutuskan apakah siswa sudah berhasil atau belum. Masing-masing kegiatan saling berkaitan satu sama lainnya. Artinya, evaluasi tidak bisa berlangsung tanpa merancang seperangkat alat tes, memberikan tes, mengukur hasil belajar siswa dan memberikan penilaian terhadap hasil belajar itu.

Hasil wawancara dengan guru di SDN 156/X Tanjung Solok, diperoleh gambaran bahwa guru cenderung: (1) belum mampu membuat tes atau mengevaluasi siswanya dengan baik, (2) membuat tes ketika diperlukan saja, dan tanpa memikirkan syarat-syarat atau kriteria tes yang benar, (3) tidak begitu memikirkan apakah tes yang dibuat dapat dijawab oleh siswa, terlalu mudah atau terlalu sulit. Hasil wawancara di atas diperkuat oleh jawaban yang diberikan oleh beberapa orang guru kelas tersebut yang dijaring melalui sejumlah pertanyaan dalam angket terbuka. Berdasarkan jawaban yang mereka berikan diperoleh gambaran bahwa: (1) guru hanya mengenal istilah-istilah evaluasi, tetapi belum mengerti tentang pengertian, maksud dan cara melakukannya dengan baik, (2) kurang memahami konsep validitas, reliabilitas, tingkat kesukaran soal, daya beda dan fungsi pengecoh, (3) jarang menyusun soal merujuk kepada pedoman penyusunan soal yang ada, (4) soal cenderung disusun berdasarkan pengalaman dan pengetahuan apa adanya, (5) soal cenderung disusun sesaat menjelang ujian akan dilaksanakan, (6) hanya memanfaatkan perangkat soal yang dibuat oleh beberapa penerbit buku dan penerbit Lembaran Kerja Siswa (LKS) yang belum diuji keterandalannya.

Dari beberapa fakta di atas dapat disimpulkan bahwa pengetahuan maupun kinerja guru dalam membuat alat evaluasi yang bermutu perlu ditingkatkan. Permasalahan ini memerlukan usaha pemecahan tepat. Apabila dibiarkan begitu saja dikhawatirkan mutu evaluasi sekaligus mutu pendidikan di tanah air akan semakin menurun. Berdasarkan masalah yang terjadi di SDN 156/X Tanjung Solok, peneliti sebagai kepala sekolah di sekolah ini sehingga sangat diperlukan adanya pelatihan dan pembimbingan kepada guru untuk meningkatkan kinerja evaluasi melalui supervisi klinis. Bafadal (2004) membuat intisasi bahwa, supervisi klinis sebagai satu bentuk aplikasi praktis supervisi pengajaran, yang merupakan satu strategi yang sangat berguna dalam supervisi, sebagai pengembangan pengajaran guru. Supervisi klinis diperkenalkan dan dikembangkan oleh Morris L. Cogan, Robert Goidhammer, dan Richart Weller di Universitas Harvard. Pada mulanya supervisi klinis ini memang dirancang sebagai salah satu model atau pendekatan dalam melaksanakan supervisi pengajaran terhadap calon guru yang sedang berpraktik mengajar. Selanjutnya, digunakan sebagai satu model supervisi pengajaran. 
Berdasarkan masalah yang telah dituturkan diatas, maka peneliti tertarik untuk melakukan penelitian tindakan sekolah yang bertujuan untuk mendapatkan data/informasi dan membahas tentang peningkatan kemampuan evaluasi guru melalui supervisi klinis pengawas di 156/X Tanjung Solok tahun ajaran 2021/2022.

Dalam UU No.14 tahun 2005 dijabarkan bahwa Sebagai agen pembelajaran, guru merupakan kunci utama keberhasilan pendidikan, sehingga tidak mengherankan jika kemudian guru menjadi pihak yang dianggap paling bertanggungjawab terhadap baik-buruknya kualitas pendidikan. Oleh sebab itu, fungsi utama guru adalah meningkatkan mutu pendidikan nasional. Pasal 1 butir 20 UU No. 20 Tahun 2003 tentang Sistem Pendidikan Nasional, dinyatakan bahwa pembelajaran adalah proses interaksi peserta didik dengan pendidik dan sumber belajar pada suatu lingkungan belajar. Di lingkungan sekolah menengah, interaksi tersebut terjalin antara siswa dengan guru. Intraksi yang berpusat pada siswa (student centered learning) diharapkan dapat terjadi proses perubahan yang dialami oleh siswa dalam empat ranah.

Lebih lanjut, Stephen P. Robbins \& Timonthy A. Judge (2009: 57-61) menyatakan bahwa kemampuan keseluruhan seorang individu pada dasarnya terdiri atas dua kelompok faktor, yaitu: a) Kemampuan Intelektual (Intelectual Ability), merupakan kemampuan yang dibutuhkan untuk melakukan berbagai aktifitas mental (berfikir, menalar dan memecahkan masalah). b) Kemampuan Fisik (Physical Ability), merupakan kemampuan melakukan tugas-tugas yang menuntutstamina, ketrampilan, kekuatan, dan karakteristik serupa. Kemampuan (ability) berarti kapasitas seorang individu untuk melakukan beragam tugas dalam suatu pekerjaan. (Stephen P. Robbins \& Timonthy A. Judge, 2009: 57).

Kemampuan yang dimiliki oleh manusia merupakan bekal yang sangat pokok. Kemampuan ini telah berkembang selama berabad-abad yang lalu untuk memperkaya diri dan untuk mencapai perkembangan kebudayaan maupun pendidikan yang lebih tinggi. Kemajuan zaman semakin cepat maka guru dituntut dapat beradaptasi secara menyeluruh baik terhadap pelaksanaan pendidikan maupun keterampilan tertentu yang melingkupinya, di samping faktor kepribadian yang semakin mantap dan meyakinkan, maka perlu adanya kompetensi.

Kemampuan guru adalah kompetensi yang diwujudkan dalam bentuk penguasaan pengetahuan dan perbuatan secara profesional dalam menjalankan fungsi dan tugas sebagai guru. Menurut Prayitno (2002) kompetensi guru diartikan sebagai pengetahuan, keterampilan dan nilai-nilai dasar yang direfleksikan dalam kebiasaan berpikir dan bertindak yang bersifat dinamis, berkembang dan dapat diraih setiap waktu. Sebelum evaluasi dilakukan, evaluator perlu melakukan beberapa kegiatan yang mendahuluinya yaitu, (1) merancang tes, (2) melakukan penilaian (assessment) dan (3) melakukan pengukuran (measurement). Nitko (1990:4) mengemukakan evaluator perlu membedakan tiga kegiatan ini, karena satu sama lainnya saling terkait.

Evaluasi yang baik adalah evaluasi yang memenuhi syarat konteks (materi, rencana tujuan, dsb) maupun konstruk (validitas, reliabilitas, tingkat kesukaran soal dan daya beda soal yang baik). 
Keputusan tentang suatu butir tes apakah dikategorikan baik atau dipakai tergantung kepada kebutuhan dan kebijakan siperancang tes atau syarat mana yang diharapkan terpenuhi. Wiersma dan Jurs (1990:48-50) tujuan tes antara lain, (2) memprediksikan status dan kemampuan siswa, (3) mengetahui perbedaan siswa, siapa yang lemah dan siapa yang pintar, (4) mengetahui pencapaian hasil, (5) estimasi domain, (6) bahan diagnosis dan (7) menetapkan keputusan. Bersamaan dengan itu fungsi tes menurut Djaali, dkk adalah: (1) sebagai alat untuk mengukur prestasi belajar siswa, (2) sebagai motivator dalam pembelajaran, dan (3) upaya perbaikan kualitas pembelajaran.

Untuk mendapatkan tes yang baik khususnya tes objektif bentuk pilihan ganda, maka guru sebagai evaluator dianjurkan melakukan beberapa kegiatan antara lain: (1) mengembangkan spesifikasi tes, (2) menulis soal, (3) menelaah soal, (4) mengujikan soal. Menurut Suryabrata (1987:2) menjelaskan bahwa dalam mengembangkan spesifikasi tes kegiatan yang dilakukan di antaranya: membuat tujuan pembelajaran, menyusun kisi-kisi soal, merencanakan dan mempertimbangkan taraf kesukaran soal.

Di dalam menulis soal guru dianjurkan melakukannya sendiri karena penulisan soal pada dasarnya adalah semacam penciptaan kreasi yang lebih merupakan kiat atau seni daripada ilmu. Kebiasaan guru membuat soal berpengaruh terhadap mutu soal itu sendiri. Sedikitnya ada enam hal yang perlu dipenuhi oleh perancang soal sehingga mendapatkan soal yang baik yaitu: (1) penguasaan akan pengetahuan yang akan diteskan, (2) kesadaran akan tata nilai yang mendasari pendidikan, (3) pemahaman karakteristik individu, (4) kemampuan membahasakan gagasan, (5) penguasaan teknik penulisan soal dan (6) kesadaran akan kelemahan dan kekuatan membuat soal. Selanjutnya dijelaskan bahwa, penguasaan guru terhadap pengetahuan yang akan diteskan tidak selalu sempurna. Guru mempunyai sisi kelemahan tentang materi ajar yang ia pegang. Apabila kendala ini dihadapi maka guru dianjurkan melakukan kerjasama atau kolaborasi dalam menyusun soal, memanfaatkan teman sejawat atau pakar.

Pemahaman umum bahwa peranan utama dari supervisi adalah ditujukan kepada perbaikan pengajaran. Franseth Jane dalam Piet A. Sahertian, berkeyakinan bahwa supervisi akan dapat memberi bantuan terhadap program pendidikan melalui bermacam-macam cara sehingga kwalitas kehidupan akan diperbaiki olehnya. Ayer, Frend E, menganggap fungsi supervisi untuk memelihara program pengajaran yang ada dengan sebaik-baiknya sehingga ada perbaikan. Menurut Kamus Besar Bahasa Indonesia supervisi berarti pengawasan utama, pengontrolan tertinggi, penyeliaan (2002:1107). Sedangkan klinis memiliki arti bersangkutan atau berdasarkan pengamatan klinis (575). Sedangkan supervisi klinis termasuk bagian dari supervisi pengajaran. Dikatakan supervisi klinis karena prosedur pelaksanaannya lebih ditekankan kepada mencari sebab-sebab atau kelemahan yang terjadi di dalam proses belajar mengajar, dan langsung pula diusahakan bagaimana cara memperbaiki kelemahan atau kekurangan tersebut (Purwanto, 2004:90).

Supervisi memiliki pemahaman yang luas (Purwanto, 2004: 76). Menurut Purwanto menjelaskan bahwa supervisi adalah segala bantuan dari para pemimpin sekolah, yang tertuju pada 
perkembangan kepemimpinan guru-guru dan personel sekolah lainnya di dalam mencapai tujuantujuan pendidikan. Ia berupa dorongan, bimbingan, dan kesempatan bagi pertumbuhan keahlian dan kecakapan guru-guru, serta bimbingan dalam usaha pelaksanaan pembaharuan-pembaharuan dalam pendidikan dan pengajaran, pemilihan alat-alat pelajaran dan metode pembelajaran yang lebih baik, cara-cara penilaian yang sistematis terhadap fase seluruh proses pengajaran dan sebagainya.

Senada dengan hal tersebut John J Bolla menyatakan supervisi klinis adalah supervisi yang difokuskan pada perbaikan pembelajaran melalui siklus yang sistematis mulai tahap perencanaan, pengamatan, dan analisis yang intensif terhadap penampilan pembelajaran guru dengan tujuan untuk memperbaiki proses pembelajaran (John Bolla dalam Mukhtar dan Iskandar, 2009:60). Purwanto juga menjelaskan bahwa Richard Waller memberikan definisi tentang supervisi klinis sebagai berikut: "Supervisi klinis adalah supervisi yang difokuskan pada perbaikan pengajaran dengan melalui siklus yang sistematis dari tahap perencanaan, pengamatan, dan analisis intelektual yang intensif terhadap penampilan mengajar sebenarnya dengan tujuan untuk mengadakan modifikasi yang rasional”.

Adapun Keith Anderson dan Meredith D. Gall mengemukakan bahwa supervisi klinis adalah proses membantu guru memperkecil ketidaksesuaian atau kesenjangan antara tingkah laku mengajar yang nyata dengan tingkah laku mengajar yang ideal. Secara teknik mereka mengatakan bahwa supervisi klinis adalah suatu model supervisi yang terdiri atas tiga fase, yaitu pertemuan perencanaan, observasi kelas, dan pertemuan balik. Supervisi klinis adalah supervisi yang terfokus pada penampilan guru secara nyata di kelas, termasuk pula guru sebagai peserta atau partisipan aktif dalam proses supervisi tersebut (Mukhtar dan Iskandar, 2009:61).

Dari beberapa pengertian tersebut dapat disimpulkan bahwa supervisi klinis adalah suatu proses bimbingan yang bertujuan untuk membantu pengembangan professional guru, khususnya dalam penampilan mengajar, berdasarkan observasi dan analisis data secara objektif sebagai pegangan untuk perubahan tingkah laku mengajar tersebut.

\section{METODE}

\section{Setting Penelitian}

Penelitian ini adalah penelitian tindakan sekolah (PTS) yang terdiri dari dua siklus dengan mengikuti empat tahapan perencanaan, pelaksanaan, observasi dan refleksi. Penelitian ini dilaksanakan di SDN 156/X Tanjung Solok pada semester ganjil tahun ajaran 2021/2022 dengan subjek guru yang berjumlah 6 orang. Data dikumpulkan melalui lembar observasi dan dokumentasi serta dianalisis menggunakan persentase dan reduksi data.

\section{HASIL DAN DISKUSI}

\section{Paparan Data Pra Siklus}

Pra siklus merupakan kondisi awal guru sebelum peneliti melakukan kegiatan penelitian di sekolah. Selanjutnya, berdasarkan hasil data pra siklus yang diperoleh, peneliti bersama guru lain 
melakukan diskusi mengenai kelemahan guru dalam evaluasi. Kegiatan pengambilan data pra siklus dilakukan di 156/X Kampung Laut dengan jumlah guru binaan sebanyak 6 orang. Berikut ini adalah tabel perolehan nilai guru dalam melakukan evaluasi.

Tabel 1. Hasil Pra Siklus Perolehan Kemampuan Evaluasi Guru

\begin{tabular}{|c|c|c|c|}
\hline No & Nama Guru & $\%$ & Kategori \\
\hline 1 & Nuraini, S.Pd. SD & 50 & $\mathrm{D}$ \\
\hline 2 & Muzriyansah & 59 & $\bar{D}$ \\
\hline 3 & Eko Prasudi, S.Pd. & 53 & $\mathrm{D}$ \\
\hline 4 & Irma Suryani & 59 & $\mathrm{D}$ \\
\hline 5 & Kamsiah & 66 & $\mathrm{C}$ \\
\hline 6 & Syafaruddin, S.Pd. & 59 & D \\
\hline
\end{tabular}

Berdasarkan tabel di atas dapat disimpulkan bahwa dari 6 orang guru yang menjadi subjek dalam penelitian ini masih berada pada kategori kurang dan cukup yang berarti perlu adanya sebuah tindakan untuk perbaikan agar kemampuan guru dalam evaluasi pembelajrana meningkat.

Tabel 2. Rekapitulasi Hasil Pra Siklus Kemampuan Evaluasi Guru

\begin{tabular}{|c|l|c|l|}
\hline No & Indikator & $\%$ & Kategori \\
\hline 1 & Kemampuan guru dalam menggembangkan silabus & 63 & C \\
\hline 2 & Kemampuan menyusun rancangan pembelajaran (RPP) & 54 & D \\
\hline 3 & Kemampuan pengelolaan kelas & 58 & D \\
\hline 4 & $\begin{array}{l}\text { Kemampuan guru melaksanakan pembelajaran menggunakan } \\
\text { metode dan strategi pembelajaran }\end{array}$ & 50 & D \\
\hline 5 & Kemampuan guru dalam memanfaatkan media dan sumber belajar & 50 & D \\
\hline 6 & $\begin{array}{l}\text { Kemampuan guru dalam menentukan pendekatan dan cara } \\
\text { eveluasi }\end{array}$ & 50 & D \\
\hline 7 & Kemampuan guru dalam meyusun alat evaluasi & 67 & C \\
\hline 8 & $\begin{array}{l}\text { Kemampuan guru dalam pengeolahan dan penggunaan hasil } \\
\text { belajar }\end{array}$ & 71 & B \\
\hline
\end{tabular}

Berdasarkan hasil observasi serta analisis dari tabel hasil pra siklus perolehan kemampuan evaluasi guru, maka dapat diperoleh bahwa dari 8 orang guru di SDN 156/X Tanjung Solok yang berada dibawah binaan peneliti ditemukan bahwa kemampuan eveluasi pembelajaran guru masih rendah dilihat dari indikator-indikator yang dinilai sehingga perlu adanya perbaikan untuk mencapai hasil yang maksimal. Berdasarkan pemaparan tabel di atas, maka peneliti sebagai kepala sekolah di SDN 156/X Tanjung Solok ingin mengadakan perubahan terhadap keluhan serta masalah guru-guru yang berada dibawah binaan peneliti. Maka setelah dilakukan diskusi dengan kepala sekolah, peneliti ingin mengadakan supervisi klinis guna untuk memberikan pencerahan terhadap guru yang bermasalah dalam evaluasi. 


\section{Siklus I}

Pengamatan dilaksanakan terhadap 6 orang guru di SDN 156/X Tanjung Solok pada bulan September - Oktober tahun ajaran 2021/2022. Penelitian ini dilaksanakan dalam dua siklus, Berikut ini disajikan gambaran materi pembelajaran pada setiap siklus dan hasil pengamatan pada siklus 1 yang merupakan landasan pertama untuk perencanaan siklus berikutnya. Hasil dari penelitian pada siklus 1 akan menjadi tolak ukur perubahan dan perbaikan yang sesuai terhadap proses dan teknik yang akan diterapkan pada siklus II.

a. Perencanaan

Tahap perencanaan siklus I terdiri dari : 1) Koordinasi dengan warga sekolah, 2) Menentukan jadwal pelaksanaan penelitian, 3) Menyusun desain tindakan dan strateginya dalam evaluasi, 4) Kepala sekolah mengundang narasumber penelitian tindakan kelas untuk memberikan informasi tentang penulisan penelitian tindakan kelas, 5) Kepala sekolah membimbing guru melalui supervisi klinis, 6) Kepala sekolah beserta guru menentukan indikator-indikator dalam evaluasi, 7) Menyiapkan instrument penelitian, 8) Membuat lembaran observasi.

b. Pelaksanaan

Pelaksanaan tindakan dilaksanakan pada hari Kamis tanggal 16 September 2021 dan hari Kamis tanggal 23 September 2021. Pada pertemuan ini diberikan arahan dan pembekalan oleh peneliti (kepala sekolah) tentang tata cara pelaksanaan supervisi klinis dan memberikan materi tentang evaluasi. Pelaksanaan supervisi klinis dilaksanakan ruang kelas SDN 156/X Tanjung solok. Kegiatan supervisi klinis dimulai dengan pemberian motivasi kepada guru-guru untuk terus melakukan evaluasi. Karena dengan melakukan penulisan oleh seorang guru dapat meningkatkan kinerja guru, salah satunya dengan melaksanakan evaluasi. Setelah dilakukan pembukaan oleh kepala sekolah dengan menggunakan supervisi klinis dalam evaluasi, selanjutnya diberi pembekalan kepada guruguru mengenai evalusi. Setekah diberikan pembekalan, maka peneliti melakukan supervisi klinis terhadap guru-guru binaan. Setelah melakukan binaan, maka dilakukan diskusi mengenai permasalahan yang dialami guru.

c. Observasi

Setelah dilakukan pembinaan terhadap guru-guru di SDN 156/X Tanjung Solok sebanyak 6 orang, maka dapat dilihat bagaimana kemampuan evalusi guru setelah dilakukan supervsi klinis. Berikut ini adalah tabel mengenai kemampuan guru dalam evalusi:

Tabel 3. Hasil Siklus I Perolehan Kemampuan Evaluasi Guru

\begin{tabular}{|r|l|r|l|}
\hline No & Nama Guru & $\%$ & Kategori \\
\hline 1 & Nuraini, S.Pd. SD. & 69 & C \\
\hline 2 & Muzriyansah & 72 & B \\
\hline 3 & Eko Prasudi, S.Pd. & 75 & B \\
\hline 4 & Irma Suryani & 75 & B \\
\hline 5 & Kamsiah & 75 & B \\
\hline 6 & Syafaruddin, S.Pd. & 66 & C \\
\hline
\end{tabular}


Berdasarkan tabel di atas dapat disimpulkan bahwa terjadi peningkatan kemampuan evaluasi guru dibandingkan dengan pra siklus. Siklus I kemampuan evaluasi guru sudah meningkat karan sudah tidak ada lagi guru yang berada pada kategori kurang dan dari 6 orang guru ada 4 orang guru yang sudah berada pada kategori baik dan 2 orang guru berada pada kategori cukup. Berikut akan dijelaskan hasil kemampuan eveluasi guru dilihat dari indikator-indikotor penilaian yang telah dilaksanakan, dapat dilihat pada tabel beriku ini:

Tabel 4. Rekapitulasi Hasil Siklus II Perolehan Kemampuan Evaluasi Guru

\begin{tabular}{|r|l|r|l|}
\hline No & \multicolumn{1}{|c|}{ Indikator } & \multicolumn{1}{|c|}{$\%$} & Kategori \\
\hline 1 & Kemampuan guru dalam menggembangkan silabus & 79 & B \\
\hline 2 & Kemampuan menyusun rancangan pembelajaran (RPP) & 67 & C \\
\hline 3 & Kemampuan pengelolaan kelas & 67 & C \\
\hline 4 & $\begin{array}{l}\text { Kemampuan guru melaksanakan pembelajaran menggunakan } \\
\text { metode dan strategi pembelajaran }\end{array}$ & 67 & C \\
\hline 5 & $\begin{array}{l}\text { Kemampuan guru dalam memanfaatkan media dan sumber } \\
\text { belajar }\end{array}$ & 71 & B \\
\hline 6 & $\begin{array}{l}\text { Kemampuan guru dalam menentukan pendekatan dan cara } \\
\text { eveluasi }\end{array}$ & 67 & C \\
\hline 7 & Kemampuan guru dalam meyusun alat evaluasi & 79 & B \\
\hline 8 & $\begin{array}{l}\text { Kemampuan guru dalam pengeolahan dan penggunaan hasil } \\
\text { belajar }\end{array}$ & 79 & B \\
\hline
\end{tabular}

Berdasarkan hasil observasi serta analisis dari tabel hasil siklus perolehan kemampuan guru dalam evaluasi setelah menggunakan supervisi klinis maka dapat diperoleh bahwa dari 6 orang guru di SDN 156/X Tanjung Solok yang berada di bawah binaan peneliti ditemukan bahwa sudah ada peningkatan kemampuan evaluasi guru. dari 8 indikator penilaian terdapat 4 indikator yang berada pada kategori baik yang berarti kemampuan eveluasi guru sudah meningkat yaitu kemampuan guru dalam mengembangkan silabus, kemampuan guru dalam memanfaatkan media dan sumber belajar, kemampuan guru dalam menyusun alat evaluasi, dan kemampuan guru dalam pengolahan dan penggunaan hasil belajar. Sedangkan 4 indikator lainnya yaitu kemampuan guru dalam menyusun rancangan RPP, kemampuan pengelolaan kelas, kemampuan guru melaksanakan pembelajaran dengan menggunakan metode dan strategi pembelajaran dan kemampuan guru dalam menentukan pendekatan dan cara evaluasi masih berada pada kategori cukup, hal ini berarti perlu adanya perbaikan lebih lanjut atau tindakan yang dapat meningkatkan kemampuan evaluasi guru tersebut.

\section{d. Refleksi}

Berdasarkan hasil diskusi peneliti dengan kolaborator yang dilaksanakan pada hari Sabtu tanggal 25 September 2021 ruang kepala sekolah SDN 156/X Tanjung Solok yang dibantu oleh seorang observer yang bernama Sumarni, S.Pd.I. masih ditemukan beberapa kelemahan yaitu: guru masih malu-malu dalam mengungkapkan masalah nya dalam melakukan evaluasi, guru kurang terbuka dalam melakukan evaluasi, guru malu bertanya jika terjadi kebingungan selam proses supervisi klinis berlangsung. Maka berdasarkan masalah tersebut peneliti berharap agar guru terbuka dalam masalah 
yang dihadapinya, guru harus aktif jika merasa kesulitan dalam supervisi klinis ada yang mau di tanyakan.

\section{Siklus II}

\section{a. Perencanaan}

Tahap perencanaan siklus II terdiri dari: 1) Mengumpulkan guru melalui undangan kepala sekolah, 2) Menyusun instrument, 3) Menyusun jadwal supervisi klinis mulai dari hari, tanggal, jam serta tempat pertemuan, 4) Menyiapkan materi supervisi klinis, 5) Menyuruh guru membawa bahanbahan yang dibutuhkan saat melakukan supervisi klinis, 6) Menyiapkan konsumsi untuk pertemuan, 7) Menyuruh guru membawa laptop dan media lain yang dibutuhkan, 8) menyiapkan hadiah.

b. Pelaksanaan

Pelaksanaan penelitian pada siklus II dilaksanakan pada hari Senin tanggal 4 Oktober 2021 dan hari Senin tanggal 11 Oktober 2021. Pada pertemuan ini dalam pelaksanaan tindakan ini, yang akan dilakukan antara lain adalah sebagai berikut: Peneliti/kepala sekolah menyampaikan konsep serta pelaksaan penelitian, Memulai melakukan supervisi klinis dengan guru-guru yang sudah dikumpulkan, Meminta guru mengutarakan masalah yang dihadapi dalam melaksanakan penilaian, Membimbing guru dalam mengatasi masalah yang dihadapi, Melakukan percobaan serta meminta evaluasi guru terhadap perkembangan yang dinilai, Melakukan tanya jawab mengenai masalah yang telah disupervisikan.

c. Observasi

Setelah dilakukan pembinaan terhadap guru-guru di SDN 156/X Tanjung Solok penuh sebanyak 6 orang, maka dapat dilihat bagaimana kemampuan evalusi guru setelah dilakukan supervsi klinis pada siklus II. Berikut ini adalah tabel mengenai kemampuan guru dalam evaluasi:

Tabel 5. Hasil Siklus II Perolehan Kemampuan Evaluasi Guru

\begin{tabular}{|c|c|c|c|}
\hline No & Nama Guru & $\%$ & Kategori \\
\hline 1 & Nuraini, S.Pd. SD & 97 & A \\
\hline 2 & Muzriyansah & 81 & A \\
\hline 3 & Eko Prasudi, S.Pd. & 88 & A \\
\hline 4 & Irma Suryani & 81 & A \\
\hline 5 & Kamsiah & 81 & A \\
\hline 6 & Syafaruddin, S.Pd. & 81 & A \\
\hline
\end{tabular}

Berdasarkan tabel di atas dapat disimpulkan bahwa dari 6 orang guru yang menjadi subjek dalam penelitian ini semua guru tersebut sudah berada pada kategori amat baik. Hal ini bererti kemapuan evalusai guru sudah meningkat dari siklus sebelumnya. Berikut akan dijelaskan hasil kemampuan eveluasi guru dilihat dari indikator-indikotor penilaian yang telah dilaksanakan, dapat dilihat pada tabel berikut ini: 
Tabel 6. Rekapitulasi Hasil Siklus II Perolehan Kemampuan Evaluasi Guru

\begin{tabular}{|r|l|c|c|}
\hline No & \multicolumn{1}{|c|}{ Indikator } & \% & Kategori \\
\hline 1 & Kemampuan guru dalam menggembangkan silabus & 92 & $\mathrm{~A}$ \\
\hline 2 & Kemampuan menyusun rancangan pembelajaran (RPP) & 79 & $\mathrm{~B}$ \\
\hline 3 & Kemampuan pengelolaan kelas & 83 & $\mathrm{~A}$ \\
\hline & $\begin{array}{l}\text { Kemampuan guru melaksanakan pembelajaran menggunakan } \\
\text { metode dan strategi pembelajaran }\end{array}$ & 79 & $\mathrm{~B}$ \\
\hline & $\begin{array}{l}\text { Kemampuan guru dalam memanfaatkan media dan sumber } \\
\text { belajar }\end{array}$ & 83 & $\mathrm{~A}$ \\
\hline & $\begin{array}{l}\text { Kemampuan guru dalam menentukan pendekatan dan cara } \\
\text { eveluasi }\end{array}$ & 83 & $\mathrm{~A}$ \\
\hline 7 & Kemampuan guru dalam meyusun alat evaluasi & 88 & $\mathrm{~A}$ \\
\hline & $\begin{array}{l}\text { Kemampuan guru dalam pengeolahan dan penggunaan hasil } \\
\text { belajar }\end{array}$ & 92 & $\mathrm{~A}$ \\
\hline
\end{tabular}

Berdasarkan tabel di atas dapat disimpulkan bahwa dari 8 indikator penilaian kemampuan evaluasi guru terdapat 2indikator yang berada pada kategori baik yaitu kemampuan guru menyusun rancangan pembelajaran (RPP) dan kemampuan guru melaksanakan pembelajaran menggunakan metode dan strategi pembelajaran. sedangakan 6 indikator lainnya sudah berada pada kategori amat baik. Hal ini berarti pada siklus II kriteria ketuntasan ynag ditetapkan oleh penulis sudah tercapai. Berdasarkan hasil analisis data hasil kerja guru, dapat disimpulkan bahwa pelaksanaan supervisi klinis dapat meningkatkan kemampuan evaluasi guru. Dilihat dari semua indikator yang dikemukakan dari penelitian secara total, rata-rata kemampuan evaluasi sudah mencapai target yang diinginkan. Artinya semua guru sudah mampu melakukan evaluasi dengan baik. Dan Dari hasil diskusi dengan kolaborator diketahui bahwa pada siklus II ini target sudah tercapai dan tidak perlu dilanjutkan ke siklus berikutnya.

\section{Diskusi}

Berdasarkan temuan dari penelitian pada siklus I dua kali pertemuan dengan judul penelitian yaitu: peningkatan kemampuan evaluasi guru melalui supervisi klinis pengawas di SDN 156/X Tanjung Solok. Dengan melaksanakan supervisi klinis secara konsisten, maka kemampuan evaluasi guru dapat meningkat. Berdasarkan penuturan yang diungkapkan oleh Purwanto menjelaskan bahwa supervisi adalah segala bantuan dari para pemimpin sekolah, yang tertuju pada perkembangan kepemimpinan guru-guru dan personel sekolah lainnya di dalam mencapai tujuan-tujuan pendidikan. Ia berupa dorongan, bimbingan, dan kesempatan bagi pertumbuhan keahlian dan kecakapan guruguru, serta bimbingan dalam usaha pelaksanaan pembaharuan-pembaharuan dalam pendidikan dan pengajaran, pemilihan alat-alat pelajaran dan metode pembelajaran yang lebih baik, cara-cara penilaian yang sistematis terhadap fase seluruh proses pengajaran dan sebagainya.

Kualitas pendidikan sangat tergantung oleh komponen-komponen yang terdapat dalam pendidikan, di antara komponen yang sangat memengaruhi berhasil atau tidaknya pendidikan adalah tergantung dari mutu guru atau bisa disebut dengan guru harus profesional. Semakin baik kualitas profesional guru akan semakin besar pula pengaruhnya terhadap peningkatan kualitas belajar 
mengajar (Idris \& Saifullah, 2005). Salah satu usaha untuk meningkatkan profesional guru adalah melalui supervisi. Supervisi pendidikan merupakan bantuan kepala sekolah atau pengawas yang menjadi supervisor untuk meningkatkan profesional guru melalui review perorangan atau kelompok mengenai ulasan masalah pendidikan dan pengembangan guna menemukan solusi dari berbagai alternatif pengembangan untuk meningkatkan profesional guru.

\section{KESIMPULAN}

Berdasarkan hasil penelitian dan pembahasan tentang peningkatan kemampuan evaluasi guru melalui supervisi klinis kepala sekolah di SDN 156/X Tanjung Solok yang telah diuraikan sebelumnya, dapat disimpulkan bahwa langkah-langkah yang dilakukan untuk meningkatkan kemampuan evaluasi guru di SDN 156/X Tanjung Solok melalui supervisi klinis adalah sebagai berikut: Penggunaan supervisi klinis cocok dalam meningkatkan kemampuan evaluasi guru di SDN 156/X Tanjung Solok.

Berdasarkan hasil penelitian, terdapat beberapa saran yang perlu dipertimbangkan oleh kepala sekolah dalam menerapkan supervisi klinis untuk meningkatkan kemampuan evaluasi guru ilmiah yaitu: 1) Kepala sekolah harus giat lagi dalam mencarikan jalan atau solusi dari setiap permasalah yang dihadapi oleh guru, 2) Disarankan kepada guru disekolah untuk mengikuti pelatihan, seminar yang berkaitan dengan pembinaan guru, 3) Penggunaan alokasi waktu dan pengelolaan kegiatan harus benar-benar diperhatikan agar pelaksanaannya dapat berjalan dengan baik dan maksimal untuk lebih memahami model pembelajaran yang aktif dan menarik.

\section{UCAPAN TERIMA KASIH}

Ucapan terima kasih sangat layak disampaikan untuk semua pihak yang telah membantu dalam pengerjaan artikel ini. Baik teman, dosen, kakak, dan yang lainnya. Artikel ini dapat dibuat karena adanya bantuan mereka. Semoga artikel ini dapat bermanfaaat untuk banyak pihak.

\section{REFERENSI}

Anonim. 2007. Peraturan Menteri Pendidikan Nasional No. 20 Tahun 2007 tentang Standar Penilaian Pendidikan.

Arikunto Suharsimi, dkk. (2005). Penelitian Tindakan Kelas. Jakarta: Bumi Aksara.

Azwar, Saifuddin. (2000). Reliabilitas dan Validitas. Yogyakarta: Penerbit Pusataka Pelajar.

Bafadal, Ibrahim. 1992. Supervisi Pengajaran. Teori dan Aplikasinya dalam Membina Profesional Guru. Jakarta: Bumi Aksara.

Depdiknas. (2004). Pengembangan Kurikulum Dan Panduan Silabus Pembelajaran Jakarta.

Mukhtar dan Iskandar. (2009). Orientasi Baru Supervisi Pendidikan. Jakarta: Gaung Persada.

Munandar, Utami. (1992). Mengembangkan Bakat dan Kreativitas Anak Sekolah Jakarta: Grasindo.

Ngalim Purwanto. (2004). Prinsip-Prinsip dan Teknik Evaluasi Pengajaran. Bandung: Rosdakarya. 
Nitko, A.J. 1990. Educational Assesment of Student. New Jersey. Merrill, an Imprint of Pretice Hall.

Pidarta, Made. (2009). Pemikiran tentang Supervisi Pendidikan. Sarana Press

Prayitno. (2002). Profesionalisasi Konseling dan Pendidikan Konselor. Jakarta: P2LPTK.

Robbins, Stephen P,1990. Organizational behavior: Concept, Controversies, applications. Englewood Cliff: Prentice Hall.

Sagala, Syaiful. (2010). Konsep dan Makna Pembelajaran. Alfabeta: Bandung

Saifullah, Ach. (2005). Melejitkan Potensi Kecerdasan Anak. Yogyakarta: Katahari

Stephen P. Robbins. (2009). Manajemen, Jilid 1. Edisi Kesepuluh. Penerbit. Erlangga.

Undang-Undang Nomor 14 Tahun 2005 tentang Guru dan Dosen

Undang-Undang Nomor 20 Tahun 2003 tentang Sistem Pendidikan Nasional

Utami Munandar. (1992). Mengembangkan Bakat dan Kreativitas Anak Sekolah, Petunjuk Bagi. Para Guru dan Orang tua. Jakarta: Gramedia

Wiersma, W., \& Jurs, S.G. (2009). Research Methods in Education an. Introduction. US: Pearson Education, Inc.

William, Wiersma dan Stephen G. Jurs, 1990. Educational Measurement and Testing, 2nd Edition. Boston: Allyn and Bacon. 